\title{
BOTTOM LINES AND WAIST LINES: STATE GoveRNMENTS WEIGH IN ON WELLNESS
}

\author{
Cynthia A. Baker*
}

\section{TABLE OF CONTENTS}

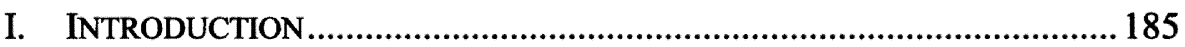

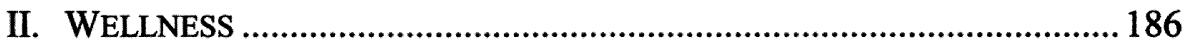

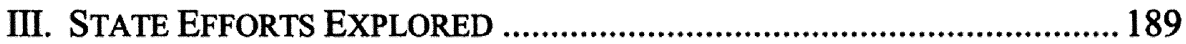

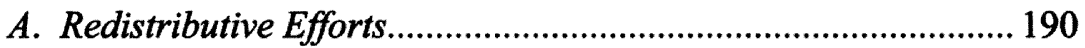

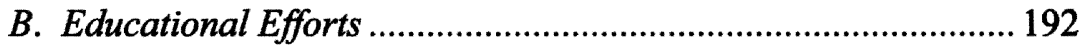

C. Community Design Efforts ....................................................... 193

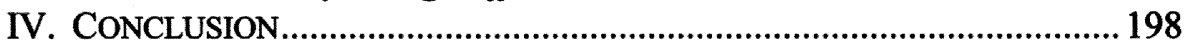

\section{INTRODUCTION}

This article springs from a unique aspect of my work as the Director of the Program on Law and State Government ("PLSG"), namely, serving as the faculty advisor for the PLSG Fellowship. ${ }^{2}$ The PLSG Fellows for 2007, Mr. Samuel Derheimer ${ }^{3}$ and Ms. Sally Hubbard ${ }^{4}$ chose wellness as the topic for their Fellowship year. Together, their questions, ideas, and work resulted in the sev-

* Clinical Associate Professor of Law and Director, Program on Law and State Government, Indiana University School of Law - Indianapolis; B.A., with distinction, 1998, Valparaiso University; J.D., magna cum laude, 1991, Valparaiso University School of Law. The Program on Law and State Government thanks the Indiana Health Law Review for its support of the 2007 Fellowship Symposium and for continuing the dialog between state governments and the academic community with this issue.

2. Awarded on a competitive basis, the PLSG Fellowships allow two students the opportunity to work together for one year exploring a topic of their choice concerning a critical legal issue facing state governments. Working with the guidance of the Director, Fellowship responsibilities have included hosting an academic event, collaborating to write an academic paper on the chosen Fellowship topic, or contributing to policy development and analysis at the state government level. Information on the PLSG Fellowship program is available at, Program on Law and State Government: Fellowships, http://indylaw.indiana.edu/programs/law_state_gov/ fellowships.htm (last visited Apr. 8, 2008).

3. J.D. Candidate, 2008, Indiana University School of Law - Indianapolis; B.A., 2002, University of Notre Dame.

4. J.D. Candidate, 2008, Health Law Concentration, Indiana University School of Law Indianapolis; M.Ed., 2000, University of Georgia; B.A., 1999, Indiana University. 
enth annual PLSG Fellowship Symposium, Wellness and the Law: State Governments' Role in Addressing America's Public Health Crisis. ${ }^{5}$

The symposium faculty included an economist, Professor Frank Chaloupka, ${ }^{6}$ who shared research regarding economic and health correlations between raising taxes and unhealthy behaviors such as smoking, alcohol consumption, and consumption of junk food, two policymakers, Professor Kevin Ryan ${ }^{7}$ and Joy Rockenbach, ${ }^{8}$ who together successfully implemented a statewide plan using Body Mass Index ("BMI") data as a way to combat obesity in school aged children; ${ }^{9}$ and Indiana's Deputy State Health Commissioner, Mary Hill, ${ }^{10}$ who addressed the aggressive advertising campaigns of tobacco companies toward young women and an innovative public/private collaboration to combat that effort. Also contributing to the day's discussion was exercise physiologist Professor Russell Pate, who shared his research regarding, primarily, how very little exercise America's children undertake compared to what they need and the health impacts of this statistic. ${ }^{11}$ The Fellows also contributed their scholarship at the event. Ms. Hubbard addressed state efforts toward encouraging wellness through public education, and Mr. Derheimer gave a legal and political history of compulsory vaccination and health security. A panel comprised of Professor Eleanor Kinney, ${ }^{12}$ Professor and Indiana Representative

5. The symposium was held on October 5,2007 , in the Wynne Courtroom of the Indiana University School of Law - Indianapolis.

6. Ph.D., 1988, City University of New York; B.A., 1984, John Carroll University. Dr. Frank Chaloupka serves as the Distinguished Professor of Economics, in the College of Business Administration and the Director of the Health Policy Center at the University of Illinois Chicago. In addition to the expansive research and scholarship that Dr. Frank Chaloupka has contributed to the area of taxing toward health, he has served as consultant to numerous governmental agencies, private organizations, and businesses.

7. B.S., 1981, University of Arkansas; M.A., 1996, Webster University, St. Louis, Missouri (Little Rock campus); J.D., with high honors, 2007, University of Arkansas at Little Rock William H. Bowen School of Law.

8. B.S.E., 1990, University of Central Arkansas.

9. Since its implementation in 2003, the Arkansas BMI project has raised issues of privacy, public records, and complex issues of health law, state priorities, and racial and ethnic disparities in existing healthcare services. Kevin Ryan, Exec. Dir., Ark. Ctr. for Health Improvement Univ. of Ark. for Med. Sci. Coll. of Pub. Health, Address at the Indiana University School of Law - Indianapolis PLSG Fellowship Symposium: Act 1220: Arkansas's Effort to Use Body Mass Index as a Political Tool (Oct. 5, 2007) [hereinafter Ryan Address].

10. B.S, summa cum laude, 1984, University of Cincinnati; J.D., summa cum laude, 1995, Indiana University School of Law - Indianapolis.

11. B.S., 1968, Springfield College; M.S., University of Oregon, 1973; Ph.D., University of Oregon, 1974. Dr. Russell Pate currently serves as the Associate Vice President for Health Sciences and Professor in the Department of Exercise Science in the Arnold School of Public Health at the University of South Carolina. Widely published and well regarded as a scholar, author, teacher, and community leader, Dr. Pate has changed the way this country thinks about physical education, obesity, and children's health. In addition, he has competed in three U.S. Olympic trial marathons and twice placed among the top finishers in the Boston Marathon.

12. M.P.H., 1979, University of North Carolina; J.D., 1973, Duke University; M.A. 1970, 
David Orentlicher, ${ }^{13}$ and Ms. Ellen Whitt, ${ }^{14}$ Indiana's Senior Advisor on Health Promotion for Indiana's Governor Mitch Daniels, presented an update on Indiana's efforts toward wellness. I too presented remarks, which served as the seeds of this article.

What are states doing to make their citizens less sick, less fat, and more well? What is the role of state government in incentivizing wellness? Finally, what are the best tools states can use to improve their citizens' attitudes toward and abilities to live healthier lifestyles? Part II of this article explores wellness and its current political landscape. Part III explores some of the most innovative ideas being tested by various state governments using redistributive, educational, and community design policy vehicles. In conclusion, I suggest that community design efforts may be the states' strongest suit in making a difference in our state of wellness.

\section{WELLNESS}

This topic begs the question, "what is wellness?" According to Stedman's Medical Dictionary "wellness" is defined as:

A philosophy of life and personal hygiene that views health as not merely the absence of illness but the full realization of one's physical and mental potential, as achieved through positive attitudes, fitness training, a diet low in fat and high in fiber, and the avoidance of unhealthful practices (smoking, drug and alcohol abuse, overeating). ${ }^{15}$

Like rainbows and puppy dogs, it's easy to be in favor of, and downright difficult to be against, wellness so defined. However, in the world of law and politics, wellness applied is not always so painlessly loved.

The political landscape of wellness has many interesting features, but I will briefly describe just a few revealing characteristics of that landscape. On one end of the continuum, we see the groups asserting that "states retain the ultimate responsibility for protecting the health of their citizens."16 These

University of Chicago; B.A., 1969, Duke University. Eleanor Kinney is the Hall Render Professor of Law and Co-Director of the William S. and Christine S. Hall Center for Health, Indiana University School of Law - Indianapolis, Indiana.

13. J.D., 1986, Harvard School of Law; M.D. 1981, Harvard Medical School; B.A., 1977, Brandeis University. Dr. David Orentlicher is the Samuel R. Rosen Professor of Law and CoDirector of the William S. and Christine S. Hall Center for Health, Indiana University School of Law - Indianapolis, Indiana.

14. J.D., 1988, George Washington University National Law Center; B.A., 1984, Augustana College. Ellen Whitt is the Senior Advisor on Health Promotion and Special Projects for Indiana's Govenor Daniels, Office of the Governor.

15. Stedman's MEDical Dictionary 1960 (28th ed. 2006) [hereinafter Stedman's].

16. Douglas Scutchfield \& William Keck, PrinciPals of PUblic Health Practice 120 
groups maintain that, taken together, stress, obesity, and illness decrease productivity and add to the costs of healthcare, doing business, and running the nation. ${ }^{17}$ A recent study by the U.S. Centers for Disease Control and Prevention and the American Diabetes Association asserts that this nation's unchecked diabetes epidemic costs our country $\$ 174$ billion a year - about, according to the study, the same amount as the conflicts in Iraq, Afghanistan, and the global war on terrorism combined - more than the $\$ 150$ billion in damage caused by Hurricane Katrina. ${ }^{18}$ For these groups, encouraging wellness would seem to be an essential element of any answer to states' health and fiscal woes.

As a result, these groups align themselves with research indicating that a majority of Americans believe that the government should actively address the obesity crisis, and contend that state governments should utilize educational programs to promote healthy living. ${ }^{19}$ These groups have had tremendous success inspiring state and local governments throughout the nation to ban smoking, ban or discourage the consumption of trans fats, and promote bully pulpit encouragement of exercise and eating right. ${ }^{20}$ It would seem, therefore, that if

(1997). Schutchfield and Keck also note that while the federal government has the most money to dedicate to the protection of public health, local governments have most of the responsibility for protecting the health of the people, and state governments have most of the legal authority to do so. Id. at 119.

17. Victoria Colliver, Chronic Illness Costs the Economy More Than \$1 Trillion a Year, S.F. CHRON., Oct. 3, 2007, available at http://www.sfgate.com/cgi-bin/article.cgi?f=/c/a/2007/ 10/03/ BUDKSGJLP.DTL (last visited Apr. 8, 2008). See Mark Winne, Replenishing Our Food Deserts: More Ways to Re-Store Our Communities, 33 STATE Legislatures 26, 28 (2007) ("Obesity and obesity-related diseases cost the Golden State [California] some \$20 billion a year . ..."). See also 2002-2003 State Health Expenditure Report, REP. (Milbank Mem'1 Fund, N.Y., N.Y.), June 2005, available at http:/www.milbank.org/reports/05NASBO/index.html (comparing state spending on healthcare by type and region) (last visited Apr. 8, 2008); Total State Government Health Expenditures as Percent of the Gross State Product, 2003, REP. (The Henry J. Kaiser Fam. Found., Menlo Park, Cal.), June 2003, http://www.statehealthfacts.org /compare maptable.jsp?cat $=5 \&$ ind $=284$ (comparing the total state government health expenditures, as a percentage of gross state product, for all U.S. states in 2003) (last visited Apr. 8, 2008).

18. See generally Am. Diabetes Ass'n, Economic Costs of Diabetes in the U.S. in 2007, 31 DiABETES CARE 3, 596 (2008).

19. New Report Finds U.S. Obesity Epidemic Continues to Grow; Mississippi Tops List for Adults, D.C. for Youths, REP. (Trust for Am. Health, Washington, D.C.), Aug. 2007, at 2, available at http://healthyamericans.org/newsroom/releases/release082707.pdf ("Eighty-one percent of Americans believe that the government should have a role in addressing the obesity crisis. Majorities strongly support government working on proposals to expand education programs about healthy living, provide low-cost access to exercise programs, and reduce the marketing of unhealthy foods.").

20. Tobacco Control: State Laws Restricting Smoking in Public Places and Workplaces, SUMMARY REP. (Am. Lung Ass'n), Mar. 2008, http://slati.lungusa.org/appendixa. asp (listing states with laws restricting smoking in public places, government buildings, and private work places) (last visited Apr. 8, 2008); NAT'L CONFERENCE OF STATE LEGIS., TRANS FAT AND MENU LABELING LEGISLATION (2008), http:/www.ncsl.org/programs/health/trans fatmenulabelingbills.htm (listing proposed and enacted state legislation relating to trans fat bans and restrictions and proposed state legislation relating to the inclusion of trans fat information on menus) (last 
any state governments should be paying attention to the bottom line and waist line data upon which these groups build their policy positions, they should include the states where many of the Indiana Health Law Review's readers live and work, Indiana and the Midwestern states generally, smack in the middle of, as one author put it, "America's obesity belt."21

On the other end of the political spectrum, groups such as restaurant associations, industrial and agricultural corporate business interests, anti-tax movements, and civil rights advocates, assert that government initiatives in this area are wholly invasive, ineffective, unnecessary, and inappropriate. ${ }^{22}$ These groups imply that at best, in the dynamic tension between the promotion of public wellness efforts and personal liberties, government wellness initiatives compromise citizens' individual rights and individualism while needlessly cutting away at the profit margins of corporate America. At worst, they imply that to the extent government supported wellness initiatives ostracize, isolate, and punish the obese, smokers, and otherwise unhealthy individuals, those initiatives should be doubly criticized because such paternalism is not properly the province of government, especially when it results in the expenditure of taxpayer dollars. Rather, these groups seem to suggest that our governments and state governments in particular have bigger fish to fry - or poach or steam or something! Issues such as unemployment, prison overcrowding, environmental degradation, and obtaining cost effective treatments for "real" illnesses, should, they aver, take precedence over the governmental promotion and subsidization of wellness.

These groups also point to the second half of the medical dictionary's definition of wellness indicating that wellness programs "tend to attract persons already attuned to healthful attitudes and practices. Little clinical evidence exists to support their usefulness or justify their expense. ${ }^{23}$ As a side note, these groups have been, in my opinion, quite effective at coining catchy phrases describing the wellness advocates of today's world. "Grease Police," "Calorie Cops," and "Exercise Radicals" are among my favorites.

\section{STATE EFFORTS EXPLORED}

State government efforts to encourage wellness can be categorized into three types: redistributive efforts, educational efforts, and community design

visited Apr. 8, 2008); NAT'l CONFERENCE OF STATE LeGis., WellNeSS OVERVIEW (2007), http://www.ncsl.org/programs/health/WellnessOverview.htm (listing states with state sponsored citizen and employee wellness programs and wellness initiatives mandated by state statute)(last visited Apr. 8, 2008).

21. Michelle Conlin, Get Healthy or Else: Inside One Company's All-out Attack on Medical Costs, BUSINESSWeEK, Feb. 26, 2007, at 58, 60. See also Kelley Holland, Wellness Programs Try to Be Welcoming, Too, N.Y. TIMES, July 22, 2007, at B17.

22. See generally Radley Balko, Does Obesity Justify Big Government?, 55 THE FREEMAN 29, 29-34 (2005), available at http://www.fee.org/pdf/the-freeman/0510Balko.pdf.

23. STEDMAN's, supra note 15, at 1960. 
efforts. Undoubtedly, state governments will need to use all three of these tools to change a culture in which overeating, under moving, and smoking ourselves sick (if not to death), has become the accepted norm. Ultimately, the manner in which state governments succeed in legislating toward wellness will provide a gauge as to how states are drawing some of the many lines between individual liberty and government authority.

\section{A. Redistributive Efforts}

Redistributive efforts are legislative responses that raise money through taxing the general public and spending the money toward specifically designated legislative ends. ${ }^{24}$ State governments are often "assigned the role of redistributing wealth throughout society in order to ensure that those worst off in the society do not fall below a given baseline."25 For example, imposing snack taxes can discourage the consumption of junk food and create a new revenue stream for health-minded initiatives such as supporting state health programs, additional health inspections, or state contributions to medical, dental, and nursing schools. ${ }^{26}$ While the positive effects of the revenue streams created by these snack taxes virtually vanish when compared to the economic costs of dietrelated diseases, "conservatively estimated to be at least $\$ 7.1$ billion annually," the recurrent rise and demise of these snack taxes illustrates the democratic tension between protecting the public health and protecting the private coffers. ${ }^{27}$

24. See generally Nathan Newman, J. Mijin Cha, \& Adam Thompson, Taking the Lead: An Interim Report on State Legislative SUccesses in Enacting Progressive Policy, INTERIM REP. (Progressive States Network, N.Y., N.Y.), June 2007, at 7-10, available at http://www.prog ressivestates.org/files/statereport.pdf. The most obvious example of states using public tax dollars to improve and create a well citizenry is the efforts aimed at increasing the scope and breadth of health benefits available to those who cannot afford private health insurance. Over the past year and a half, twenty-nine states have enacted or considered healthcare expansions aimed at children. Many initiatives expand eligibility for the State Children's Health Insurance Program ("SCHIP") to $300 \%$ (and some for up to $400 \%$ ) of the federal poverty level. As a point of reference, a state permitting coverage for a family at $300 \%$ of the poverty level would allow a family of four with a household income of $\$ 60,000$ to apply for coverage. A state permitting coverage for a family at $400 \%$ of the federal poverty level would allow a family of four with a household income of up to $\$ 82,600$ to purchase the public coverage at full cost, which is expected to be cheaper than private coverage. In addition, these state efforts are accompanied by others seeking to ease administrative barriers to enrollment and improve outreach to ensure that eligible children are signing up. Indiana expanded SCHIP to families at or below $300 \%$ of the poverty. Id.

25. Lynn A. Baker \& Clayton P. Gillette, LoCAL Government LAW 45 (2004).

26. Michael F. Jacobson \& Kelly D. Brownell, Small Taxes on Soft Drinks and Snack Foods to Promote Health, 90 AM. J. PUB. HEALTH 854, 854-57 tbl.1 (2000). See also Frank Chaloupka, Dir., Univ. of Il. at Chi. Health Pol'y Ctr., Address at the Indiana University School of Law - Indianapolis PLSG Fellowship Symposium: The Economics of Taxing Toward Health (Oct. 5, 2007) (on file with the author) [hereinafter Chaloupka Address].

27. Jacobson \& Brownell, supra note 26 , at 854-57. 
At least nine states have repealed such snack taxes in recent years. ${ }^{28}$ Most of these repeals were at the behest of large soft-drink companies and snack food corporations as a part of negotiations to build or retain one or more manufacturing facilities within the respective states. ${ }^{29}$ One noteworthy effort by bottling companies occurred in Ohio, where, in 1994, a $\$ 0.008$ per oz. tax on carbonated beverages was repealed by amending Ohio's constitution after a seven million dollar advertising campaign - funded by the soft drink industry - to defeat the tax. ${ }^{30}$

This example illustrates a common theme in states' redistributive efforts regarding wellness: corporate investment in a state government, along with the jobs, income, and wealth that companies bring with them, often holds sway over modest and well meaning state efforts to tax their citizens toward healthier choices. Clearly, the voice of the private corporate market can be more powerful than the voices of health advocates and state governments combined. Scholars point out that when state governments are strapped for tax revenue and development funds, they often find themselves "compet[ing] for resources to the detriment of the public they are supposed to serve."31

Studies show consistent evidence that a variety of health behaviors respond to changes in prices. Higher taxes which increase prices can induce current smokers to quit, prevent young people from becoming regular smokers, reduce drinking - particularly heavy/binge drinking and drinking among young people - and increase the likelihood of healthy eating. ${ }^{32}$ In addition, imposing such taxes can raise significant new revenues that can then be used to support other efforts to improve health and wellness. According to research by Professor Frank Chalupka, arguments about the adverse economic consequences of those efforts are, therefore, either false or overstated. ${ }^{33}$

On the other hand, corporate America, with and without state government intervention or incentives, provides all sorts of health and wellness benefits to its employees and their families. Research shows that "more than half of all large companies [in the U.S.] offer some combination of benefits such as nutrition education, weight management assistance, health risk assessments, and help quitting smoking. Moreover, more than a quarter offer things like fitness coaching and discounts on health club memberships." 34 So, to the extent that

28. Id.

29. Id. at $855-56 \mathrm{tbl} .2$.

30. Id. But see, School District, Coke Sign \$350,000 Deal, IndIANAPOLIS STAR, Feb. 2008 (on file with the author) (noting recent efforts by a major soda company to provide healthier alternatives and other incentives toward a healthier school environment through private contact rather than public law).

31. See Richard Thompson Ford, Beyond Borders: A Partial Response to Richard Briffault, 48 STAN. L. REV. 1173, 1183 (1996).

32. Chaloupka Address, supra note 26.

33. Id.

34. Holland, supra note 21, at B17. 
redistributive efforts are influenced by business interests, states should, at the very least, be mindful that some business interests may serve public wellness goals more than others and, when possible, take that into consideration when courting new corporate investment.

\section{B. Educational Efforts}

Given the political costs of even modest redistributive efforts toward wellness, it is hard to expect states to act more aggressively when faced with the even more slippery and tangential effects of educational efforts. As a result, most state efforts to reach out and educate and encourage toward wellness are relatively low budget public/private motivational endeavors. ${ }^{35}$ Statewide wellness programs for all citizens share characteristics such as providing web based resources for information about the benefits of eating right, exercise, and other healthy behaviors, community programs and events, smoking cessation initiatives, and awards and prizes available to citizens who participate in the program or attain particular results. ${ }^{36}$ More targeted efforts aim to educate their citizenry at key decision making points between healthy or unhealthy choices, such as at the time of food selection in restaurants. Fourteen states and four major cities in the U.S. have already introduced laws and regulations requiring that caloric information about food purchased be made more apparent - that is, either posted on menu boards or on the menus of the restaurants themselves. ${ }^{37}$

New York City ("NYC") used its regulatory powers to require restaurants that have already made public the number of calories in standardized menu items to take the next step and make that number (540 calories for a Big Mac, in case you were wondering) "readily available" to consumers as they choose food items. ${ }^{38} \mathrm{NYC}$ justified its regulation by noting that "an obesity epidemic

35. See Whitt, supra note 14 (highlighting remarks by Ellen Whitt, Senior Advisor on Health Promotion and Special Projects for Indiana's Governor Mitch Daniels).

36. Compare InShape Indiana's Ready, Set, Walk! Homepage, www.in.gov/inshape/ (last visited Apr. 21, 2008) (describing Indiana's wellness initiative), with Healthy Arkansas: For a Better State of Health Homepage, www.arkansas.gov/ha/home.html (last visited Apr. 21, 2008) (describing Arkansas's wellness initiative), Healthy Hawaii: Start Living Healthy Homepage, www.healthyhawaii.com/ (last visited Apr. 21, 2008) (describing Hawaii's wellness initiative), Building a Healthy North Dakota Homepage, www.healthynd.org/ (last visited Apr. 21, 2008) (describing North Dakota's wellness initiative), Healthy Ohio Homepage, healthyohioprogram.org/ (last visited Apr. 21, 2008) (describing Ohio's wellness initiative), and The Vermont Governor's Council on Physical Fitness and Sports Homepage, www.vermontfitness.org/ (last visited Apr. 21, 2008) (describing Vermont's wellness initiative).

37. See Ian Mount, Would You Eat 2,900-Calorie Cheese Fries?, ForTuNE: SMALL BUSINESS, Apr. 29, 2008, http://money.cnn.com/2008/04/24/smbusiness/full_disclosure_ menu.fsb/index.htm (last visited Apr. 30, 2008). See generally New York State Restaurant Ass'n v. New York City Bd. of Health, 509 F.Supp.2d 351, 351 (S.D.N.Y. 2007); New York State Restaurant Ass'n v. New York City Bd. of Health, No.08CIV.1000(RJH), 2008 WL 1777479 (S.D.N.Y. 2008).

38. Bonnie Booth, New York City Wants Calories Put on Menus, AMNEws, Sept. 10, 
threatens the health of New Yorkers." ${ }^{\text {,3 }}$ Raising federal preemption and First Amendment concerns, the New York Restaurant Association sued to stop the city from enforcing the regulation and won. ${ }^{40}$ The City's Board of Health has since retracted the calorie reporting provision, aiming to overcome the preemption concerns. ${ }^{41}$ The revised rule, like its predecessor, requires the posting of calorie information at the point of selection in fast food chain restaurants. ${ }^{42}$ Like its predecessor, the revised rule has also been challenged by the New York State Restaurant Association. ${ }^{43}$ Whether New York City's struggle will bring a quiet end to calorie information education efforts in other states and cities, or if it is just a bump in the bike trail, remains to be seen.

\section{Community Design Efforts}

Community design efforts provide another way for states to legislate towards wellness. Working with private businesses, not-for-profit organizations, economic development teams, and local governments, states remain in a unique position to physically reshape communities in ways that are good for public coffers, private balance sheets, and the personal health of the states' respective citizens. I suggest that community design efforts might be the most politically and legally viable tool to legislate toward wellness.

Examples of statewide community design based initiatives include smoking bans, ${ }^{44}$ water fluoridation mandates, ${ }^{45}$ and infrastructure improvements that

2007.

39. Id.

40. New York State Restaurant Ass'n v. New York City Bd. of Health, 509 F.Supp.2d 351, 351 (S.D.N.Y. 2007) (relying on pre-emption, the trial court did not address the First Amendment arguments); New York State Restaurant Ass'n v. New York City Bd. of Health, No.08CIV.1000(RJH), 2008 WL 1777479 (S.D.N.Y. 2008) (denying restaurant association's motion for preliminary injunction and granting city's motion for summary judgment on the issue of preemption and denying restaurant association's motion for stay of enforcement pending appeal).

41. Dep'T of Health \& Mental Hygiene, Res. to Repeal \& ReEnact § 81.50 OF THE N.Y. City HEALTH CODE (as passed by the NYC Dep't of Health, Jan. 22, 2008).

42. Id.

43. Press Release, Statement From N.Y. City Health Dep't Regarding Court Case on Calorie Posting Regulation (Mar. 27, 2008), available at home2.nyc.gov/html/doh/html/pr2008/ pr023-08.shtml (last visited Apr. 21, 2008).

44. Statestats: Smoke Free Laws, 33 StATE Legislatures 7, 7 (Sharon Randall ed.) (July 2007). Most states in the northeastern U.S., with the exception of Pennsylvania, and most states in the west and south west, and three states in the Midwest (Minnesota, Illinois, and Ohio) require most workplaces, including restaurants and bars, to be smoke free. Nine states, mostly in the west and south, ban smoking from all or most restaurants and most workplaces, but exempt some bars and restaurants from the statewide ban if, for example, the bar or restaurant does not admit patrons under age eighteen or twenty-one. More than one third of all states including Indiana considered banning smoking in cars with children in 2007. Only two states, Arkansas and Louisiana, have passed such statewide bans. Id.

45. Megan Foreman, Children's Oral Health, 15 NCSL LeGISBRIEF 1, 1 (Aug. 2007). "According to the Center for Disease Control (CDC), water fluoridation . . . is one of the 10 
encourage people to live healthier lives. ${ }^{46}$ States have plenary power to recalibrate the state and local power structure to require local governments to address local land use, zoning, and planning issues with an eye toward making it easier to be physically active by walking and biking in, around, and among various local governments. Of course, these ideals automatically trigger traditionally very local burdens such as public safety concerns, the cost of parks and recreation programs, and, of course, the basic infrastructure necessary for linear parks and trail systems between neighborhoods and towns. But these are the very areas where state governments have the most power to act and to fund collaborative regional solutions.

Ms. Hubbard's Comment, Taking Roll: An Assessment of State and Local Governance of School Wellness Policies, which also appears in this issue of the Indiana Health Law Review, explores the potential power of such regional solutions to enhance wellness by discussing how state funding formulas, educational standards, and legislation, have the power to positively impact the physical environment within our nation's schools. ${ }^{47}$ Indeed, Ms. Hubbard theorizes that by establishing nutritional standards for school lunches (with higher criteria than currently mandated under federal law), banning food courts and competitive foods from schools, increasing nutrition education and physical activity standards for all grade levels, decreasing screen time for kids in school, promoting walking to school, and creating BMI data driven initiatives, state legislatures could dramatically and positively impact the health and wellness of America's future generations. ${ }^{48}$

Parallel community design wellness efforts at the local and state government level include: improving regional and local zoning laws to accommodate trails and sidewalks, encouraging wellness based economic development, and supporting urban planning efforts that reduce the role of the automobile. Could increased access to medical care or fresh food result in measurable health improvements? Can discouraging the availability of fast food encourage healthier personal diet choices? Some state and local governments are willing to implement these sorts of community design efforts in the hopes that they will.

New Jersey led the way toward marrying a concept familiar to state governments, enterprise zones, to a public health initiative when it passed the Health Enterprise Zone Act in 2004. ${ }^{49}$ "The Health Enterprise Zone Act enables the state commissioner of health ... to designate medically underserved

greatest public health achievements of the 20th century." Still, even with CDC data reporting that every dollar invested in fluoridation saves thirty-eight dollars in avoided dental treatment costs, only eleven states mandate statewide water fluoridation. Id.

46. Ryan Address, supra note 9.

47. Sally Hubbard, Comment, Taking Roll: An Assessment of State and Local Governance of School Wellness Policies, 5 IND. Health L. Rev. 201, 201 (2008).

48. Id.

49. See, e.g., New Jersey Health Enterprise Zone Act, 2004 N.J. LAws Ch. 139. See also Comm. on Suggested State Legis., Health Enterprise Zones, 66 SUGGESTED STATE LEGISLATION 56, 56 (2007) [hereinafter Health Enterprise Zones]. 
areas as Health Enterprise Zones (HEZs) and to offer financial incentives to doctors and dentists to practice in an HEZ." a reduction of income tax owed (based on the proportion of the health professionals' gross receipts "from providing health care services to eligible recipients of the Medicaid program and [New Jersey's] state FamilyCare program"), the opportunity to apply for low interest loans "administered by the State Economic Development Authority," and, under certain circumstances, an exemption from real property tax if the municipality in which the $\mathrm{HEZ}$ is located passes an ordinance to that effect. ${ }^{51}$

Other health zoning efforts afforded by state law include South L.A.'s recent consideration of a "moratorium of up to two years on new fast-food restaurants in south L.A." 52 Thirty percent of adults and twenty-nine percent of children in south L.A. are obese, compared to twenty one percent and $23.5 \%$, respectively, of adults and children in the county. ${ }^{53}$ Of course, questions abound regarding whether local zoning laws that target obesity saturated areas in this manner can withstand legal challenge.

Pennsylvania and New Mexico are leading community design efforts aimed at increasing access to healthy food by creating better food supply systems. ${ }^{54}$ Recognizing that access to fresh produce and meat is a basic need, state legislatures and local governments are turning to the task of reducing the size and number of "food deserts" - places that, "compared to more prosperous communities, are underserved by affordable, high quality retail food outlets." For families living in these food deserts, it is ultimately too expensive, too difficult, and too time consuming to have fresh healthy food in the refrigerators and cupboards. ${ }^{56}$ Providing access to fresh food in urban and rural food deserts, however, requires significantly different solutions to the same problem. ${ }^{57}$

Pennsylvania's approach, the Fresh Food Financing Initiative, of 2004 ("FFFI"), has encouraged public and private funding for supermarket development across that state. ${ }^{58}$ To date Pennsylvania's FFFI, "has committed re-

50. Health Enterprise Zones, supra note 49, at 56.

51. Id.

52. Council Mulls Limiting Fast Food in South L.A., INDIANAPOLIS STAR, Sept. 16, 2007, at $\mathrm{A} 4$.

53. Id.

54. See generally Mark Winne, Replenishing Our Food Deserts: More Ways to Re-Store Our Communities, 33 StATE Legislatures 26, 26-28 (2007).

55. Winne, supra note 54, at 26.

56. Id.

57. See generally id.

58. Id. at 26. In a collaborative effort between the state, a development finance corporation, a nonprofit organization, and the Greater Philadelphia Urban Affairs Coalition, Pennsylvania has committed thirty million dollars that the initiative as a whole can use to leverage other private and public dollars for supermarket development. The Fresh Food Financing Initiative has committed resources to twenty eight projects that have produced more than a million square feet of retail food space and 2500 new jobs. Id. 
sources to 28 projects that so far have produced more than a million square feet of retail food space" in urban "food deserts" across the state of Pennsylvania. 59 A similar effort is underway in New Mexico and seeks to direct state funds toward getting affordable fresh food and produce to rural communities in that state. ${ }^{60}$ In New Mexico, the region's only independent food wholesaler is based in Amarillo, Texas, a situation which potentially poses a problem for food sellers attempting to reach potential customers in rural New Mexico. ${ }^{61}$ "If a store doesn't have a loading dock, for example, it's just too costly" for the wholesaler to make a delivery. ${ }^{62}$ While the New Mexico effort is still in the "task force" stage, it will likely result in "a state-financed revolving loan fund that helps cash strapped store owners in rural areas purchase produce coolers or even loading docks" to avail the stores, and the people living in the food deserts, to a wider and lower priced selection of fresh food. ${ }^{63}$

Other state initiatives aimed at improving the fresh food supply system include state supported training and technical assistance for store owners new to the produce business, offering financial incentives to food stamp recipients to buy fresh fruits and vegetables, and giving farmers a personal property tax abatement on farm equipment if they sell produce at farmers' markets in underserved communities. ${ }^{64}$

Additionally, state efforts have not ignored the communities in which Americans spend more than half of their waking hours: the workplace. Some states are exploring, but none has passed into law, policies requiring that employers guarantee some number of paid sick days per year, allowing employees to remain home when sick or to care for a loved one who is ill. ${ }^{65}$ At the local level, for example, "San Francisco has already enacted a city-wide paid sick days law, and family advocates and their allies will [continue] fighting for enactment of statewide versions . . ..,66 San Francisco's approach is not unique. Earlier this year, "Oregon followed seven other states in at least allowing those workers who have sick day benefits to also use them to care for a sick child or parent."

59. Id.

60. Id. at 27 ("[T] $]$ he task force's recommendations will be presented at the 2008 legislative session" and N.M state representative Manual Herarra foresees something more modest than Pennsylvania's FFFI.).

61. Winne, supra note 54, at 28.

62. Id.

63. $I d$.

64. Id.

65. Newman, Cha, \& Thompson, supra note 24 , at 5 ("The Connecticut Senate approved a paid sick days bill, becoming the first chamber in the nation to do so, but the bill failed to pass the Connecticut House before the session ended.").

66. Id.

67. $I d$. 
Another workplace related state effort imposes smoking bans more broadly-and indirectly - by allowing employers to ban leisure time smoking. ${ }^{68}$ This sort of ban - not limited to the geographic spaces of a workplace or a public place - is the subject of state legislation that to date has made far fewer headlines. By allowing employers to enforce a non-smoking policy as a part of their hiring and retention processes, states allow those employers who choose to, to both test employees for nicotine and fire those with the drug in their system. ${ }^{69}$

For example, Massachusetts is one of twenty-three states allowing employers to penalize employees and potential employees for smoking during nonemployment hours. ${ }^{70}$ In the fall of 2006 , just two weeks after beginning his work as a lawn care technician for Scotts Miracle Gro, Scott Rodriquez was fired for failing a drug test - for nicotine. ${ }^{71} \mathrm{Mr}$. Rodriquez has filed a law suit in federal court in Massachusetts alleging inter alia illegal discrimination. ${ }^{72}$ The suit also seeks to prohibit Scotts from enforcing or applying its antinicotine program. ${ }^{73}$ The suit is still in its preliminary stages; but, on January 30,2008 , the district court dismissed all counts relating to the plaintiff's allegations of wrongful termination and civil rights violations for failure to state any claim upon which relief could be granted. It appears, however, that Mr. Rodriquez will have the opportunity to prove his allegations regarding invasion of privacy and unlawful discrimination under the Employee Retirement Income Security Act in court. ${ }^{74}$

Other states including Indiana prohibit employers from discriminating against any current or prospective employee based on employee use of tobacco products outside the course of employment. ${ }^{75}$ But while the Rodriquez case could not happen in Indiana under current state law, last year Indiana's General Assembly clarified Indiana's statutory approach in this area by allowing em-

68. See generally Karen L. Chadwick, Is Leisure-time Smoking a Valid Employment Consideration?, 70 ALB. L. REV. 117, 117 (2006).

69. See id. at 130.

70. Conlin, supra note 21 , at 60 . "Today, Scotts is in the vanguard of companies seeking to monitor and change employee behavior." Id. Working with a boutique law firm, Scotts hired a private health management firm to provide on-site primary care and fitness centers for its employees. Scotts built a five million dollar, 24,000 square foot facility across the street from its headquarters where employees can obtain almost any primary medical or health intervention necessary - the facility employs two full-time doctors, five nurses, a dietician, counselor, two physical therapists, a team of fitness coaches, and includes a drive-thru pharmacy. Id.

71. Id.

72. Id.

73. Rodrigues v. Scotts Co., LLC, 2008 WL 251971 (D. Mass., 2008).

74. Id.

75. See, e.g., Indiana's Private Tobacco Protection Act, IND. CODE. § 22-5-4-1 (2007). "Currently, twenty-seven states and the District of Columbia have adopted statutes which prohibit enforcement of employment policies that penalize employees and potential employees for engaging in legal activities such a smoking during non-employment periods." Chadwick, supra note 68 , at 117 . 
ployers to "implement financial incentives intended to reduce tobacco use and related to employee health benefits provided by the employer." 76

\section{CONCLUSION}

State governments' active interest and support of wellness necessarily raises important issues regarding government priorities, discrimination, the rights of free speech and association, and individual choice. An integrated response requires that states use redistributive, educational, and community design efforts to encourage wellness. However, it seems that states can be the most effective when they actually work to change the physical community. That is, states' efforts will be the most effective when they concentrate on limiting or eliminating smoking, giving local governments additional tax breaks and incentives to create streets with room to walk, bike, and run, and encouraging businesses in both rural and urban communities to have fresh foods available for purchase.

As state governments try to improve environments plagued with an over abundance of non-nutritious food, obesigenic factors, and a lack of alternatives to sedentary ways to work and play, they face important political and fiscal choices. In so doing, state and local governments and their respective policy makers may find guidance in Abraham Lincoln's words of more than a century ago. In 1848, Abraham Lincoln said, "There are few things that are wholly evil or wholly good. Almost everything, especially of government policy, is an inseparable compound of the two; so that our best judgment of the preponderance between them is continually demanded."77 In Lincoln's day, America was in the midst of the industrial revolution, people lived in urban areas in previously unseen numbers, and slums and disease were an inextricable part of what it was to live in the poor areas of cities. ${ }^{78}$ Death and disease were "a daily fact for the people in the worst tenement districts." 79

Today, Americans' health and wellness are still adversely affected by the conditions of the day. However, fresh food deserts, sedentary lifestyles, and an overabundance of inexpensive, highly caloric food have largely replaced the cesspools, overcrowding, and diseases of the mid-19th century. Still, President Lincoln's words resonate as we, as citizens, lawmakers, lawyers, parents, educators, and judges, make our "best judgments" about the preponderance between good and evil when it comes to encouraging wellness. While public health has proved a powerful basis for legal reform, public wellness is on much less stable ground. The legal, political, and economic questions surrounding

76. $\S 22-5-4-1$.

77. THE COLLECTED WORKS OF ABRAHAM LinCOLN 484 (Roy P. Basler ed.) (1953) (quoting Representative Abraham Lincoln's, remarks in the House, June 20,1848).

78. Dorothy Deneen Volo \& James M. Volo, DaILY LIFE IN CIVIL WAR AMERICA 9 (1998); Michael J. Varhola, EVERYDAY LIFE DURING THE CIVIL WAR 62-73 (1999).

79. Id. at 69-71. 
state governments' interventions in wellness will surely be with us for a while. As cheerleaders, administrators, tax collectors, or architects of local government, state governments have lots of ways to weigh in and make a difference in the bottom lines and waist lines of our communities.

I laud the work of the 2007 Fellows, Mr. Sam Derheimer and Ms. Sally Hubbard, for their contribution to what was a terrific symposium, a symposium which inspired us to think about not only state governments' role, but our own, in addressing whether and how states confront this work. 
